\title{
Scorpionism by Hemiscorpius spp. in Iran: a review
}

\author{
Rouhullah Dehghani ${ }^{1}$, Fatemeh Kamiabi ${ }^{2^{*}}$ and Malihe Mohammadi
}

\begin{abstract}
Scorpions are distributed throughout Iran and the genus Hemiscorpius is particularly important in this region. Hemiscorpius lepturus is the most significant species within the genus in the country. Since scorpionism provoked by Hemiscorpius comprises a medical emergency, the present study is focused on this important issue. In order to perform the present work, a review of the medical and health-related literature was carried out in several databases. The current findings indicate that six species of Hemiscorpius are found in 15 states of Iran, mainly in the south and southwest. Deaths caused by stings were reported only for two species. The morphological characteristics and geographical distribution of $H$. lepturus in Iran, its venom and the toxic compounds, epidemiologic data and clinical manifestations of envenomation as well as treatment for affected people are herein reviewed and described. H. lepturus venom toxicity differs from other Iranian scorpions regarding duration and severity. Scorpionism is an important public health problem in Iran, especially in southwest and south regions and in urban areas. It is more prevalent in children and young people. H. lepturus venom is primarily a cytotoxic agent and has hemolytic, nephrotoxic and to some extent hepatotoxic activity. The use of polyvalent antivenom to prevent scorpion sting symptoms is recommended. A well-planned health education program might be useful in preventing scorpionism.
\end{abstract}

Keywords: Hemiscorpius, Scorpionism, Scorpion venom, Emergency, Epidemiology

\section{Background}

Venomous animals are spread throughout the globe and play an important role in the terms of ecological balance. Most species of these animals use their venom for predation or defense. Some animal venoms may be life threatening for humans whereas nontoxic animals may bite a human in defense situations $[1,2]$. Some venomous animals inject their toxins into their prey through stingers or other apparatus, whereas others use mouth annexes such as fangs in snakes or chelicerae in spiders. In the latter situation, the victim may be affected by venom and by the animal's oral flora [3-6]. Annually, 5 to 7 thousand people are bitten by snakes in Iran, and the average mortality due to snakebite is 7 to 12 people per year [7, 8]. Although snakes are usually more fearsome than other venomous animals, scorpions are more important than other species in Iran.

There is a rich fauna of venomous animals in Iran, especially concerning scorpions species [9-12]. Deaths

\footnotetext{
* Correspondence: fkamiabi@yahoo.com

${ }^{2}$ Faculty of Health, Kerman University of Medical Sciences, Kerman, Iran

Full list of author information is available at the end of the article
}

attributable to scorpion stings, which occur in all regions of the country, are more numerous than those caused by other venomous animals [13-16]. Iranian scorpions generally belong to three families: Buthidae, Hemiscorpiidae and Scorpionidae. Scorpion stings have been reported in the country for centuries since there are ancient religious and historical texts indicating their presence [17-19].

About 50,000 cases of scorpion stings are recorded in Iran annually. Epidemiological studies have showed that scorpion stings comprise the major type of envenomation in the country, with most cases happening in the southwest [20]. Clinical and laboratory symptoms of scorpionism following Hemiscorpius stings are clearly different from those reported for other medically important scorpion species [21, 22]. This phenomenon is observed in countries such as Iran, Iraq, Pakistan, Saudi Arabia, Oman, Yemen and United Arab Emirates [23]. Considering the importance of scorpionism by Hemiscorpius in Iran, the present study was carried out to investigate various aspects of this phenomenon in Iran. 
A review of the medical and health-related literature was carried out in several databases including: Medline, Web of Science, Cochrane Library Database, Scopus, Google Scholar, SID and Iran Medex. Search terms were: scorpion, medical care, Iran, Hemiscorpius, Hemiscorpius lepturus, scorpion sting, antivenom, venom, symptom, epidemiology, clinical study and distribution. The results included Persian and English language studies from 1978 to 2016. In addition, sources of medicine history of Iran before and after Islam were accessed in order to study the history of scorpionism by Hemiscorpius.

The search strategy and review process were performed according to the aims of the study, with emphasis on studies conducted in Iran, restricted to the morphological characteristics and geographical distribution of $H$. lepturus in the country, its venom and the toxic compounds, epidemiologic data and clinical manifestations of envenomation as well as treatment with antivenom. A total of 193 studies matched the search terms, and 71 of them were excluded after initial screening.

\section{Hemiscorpiidae family}

The number of species, genera and families of scorpions in the world have changed substantially in a relatively short time. By the last two decades, nearly a thousand species have been recognized and described globally [24-27]. So far, 2231 species of scorpions divided into 208 genera and 20 families have been recognized. According to the latest revision of the classification of scorpions in Iran, three families of Buthidae (51 species), Scorpionidae (three species) and Hemiscorpiidae (five species) were reported from different parts of the country [20].The Buthidae family is the largest and most abundant scorpion family in the world. Moreover, members of this family are considered the most dangerous ones [28-33].

The Hemiscorpiidae family has undergone several changes and developments during the last two decades. Because of the similarity between members of this family and those of Scorpionidae, they used to be considered as belonging to the same family in the past. Currently, this family consists of one genus (Hemiscorpius) and 15 species. Up to this moment, six species of this genus have been described in Iran (Table 1) [30, 34-36].

Table 1 The described species of Hemiscorpius genus in Iran

\begin{tabular}{ll}
\hline Genus & Species \\
\hline Hemiscorpius & Hemiscorpius acanthocercus (Monod et Lourenço, 2005) \\
& Hemiscorpius enischnochela (Monod et Lourenço, 2005) \\
& Hemiscorpius gaillardi (Vachon, 1974) \\
& Hemiscorpius lepturus (Peters, 1862) \\
& Hemiscorpius persicus (Birula, 1903) \\
& Hemiscorpius kashkayi (Karataş and Gharkheloo 2013) \\
\hline
\end{tabular}

Hemiscorpius lepturus is a dangerous species that has been found in Iran, Oman, Iraq, Saudi Arabia, Yemen, Pakistan and United Arab Emirates [37-40]. This scorpion has highly cytotoxic venom that can cause scorpionism in humans and other animals. Some researchers believe that scorpionism may be related to several species of Hemiscorpius, not only $H$. lepturus. Therefore, it is important to be able to recognize the involved species after an incident, specially because Hemiscorpius species are very similar morphologically [41]. There are records of deaths attributable to $H$. lepturus and $H$. acanthocercus.

\section{Geographic distribution of Hemiscorpius genus}

The Hemiscorpiidae family is spread throughout six countries in the Middle East, including Iran, Iraq, Pakistan, Saudi Arabia, Oman, Yemen and United Arab Emirates (Fig. 1) [23].

These scorpions are usually find in hot and humid areas. In Iran, they have been reported in the provinces of Khuzestan, Semnan, Fars, Kurdistan, Hormozgan, Sistan and Baluchestan, Isfahan, Bushehr, Kohgiluyeh and Boyer-Ahmad, Ilam, Chahar Mahal and Bakhtiari, Lorestan, Hamedan, Kermanshah and Kerman (Fig. 2) [20, 40, 42-45].

\section{The historical background of scorpinism by Hemiscorpius in Iran}

The history of Hemiscorpius stings in Iran dates back a long time $[46,47]$. One of the first reports of evenomation by Hemiscorpius in Iran was presented by Avicenna in The Canon of Medicine, an encyclopedia of medicine in five books first published in the eleventh century. $\mathrm{He}$ described the effects of venomous animal bites on humans as well as possible treatments. In addition, measures to protect humans from envenomation by animals were described.

The report was based on documents of scorpionism syndrome patients from Khuzestan. Avicenna wrote: "As a result of Gadim [the local name of Hemiscorpius spp. in Khuzestan] sting, the person does not feel any pain immediately after it. One or two days later, the injured person experiences problems caused by the sting. After that, he or she becomes a very depressed person with a pale face that may be suffering from jaundice. Tongue is swelling; the sting location is festering; urine is red colored, which means it is bloody. The patient may be suffering from constipation. Heart rate increases and the person faints, which may lead to death. It should be noted that if there is less pain, a doctor should not frail or gullible, because Gadim is highly toxic and deceptive" $[48,49]$. In addition to the clinical symptoms of Hemiscorpius stings, Avicenna also described the morphological characteristics and habitat of this scorpion species in Khuzestan and Iraq [48, 49]. 


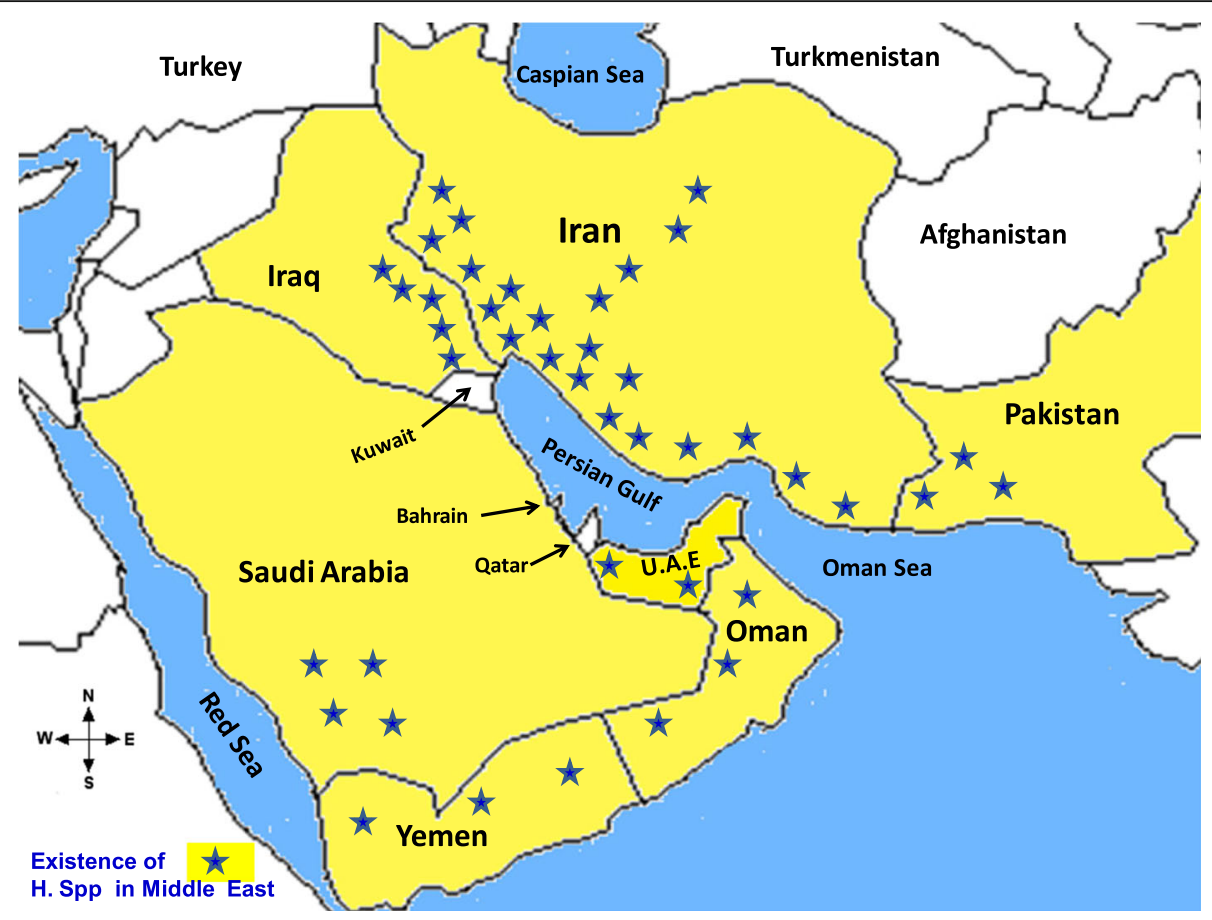

Fig. 1 Distribution of Hemiscorpius species in Middle East (image prepared by R. Dehghani, reproduced with permission)

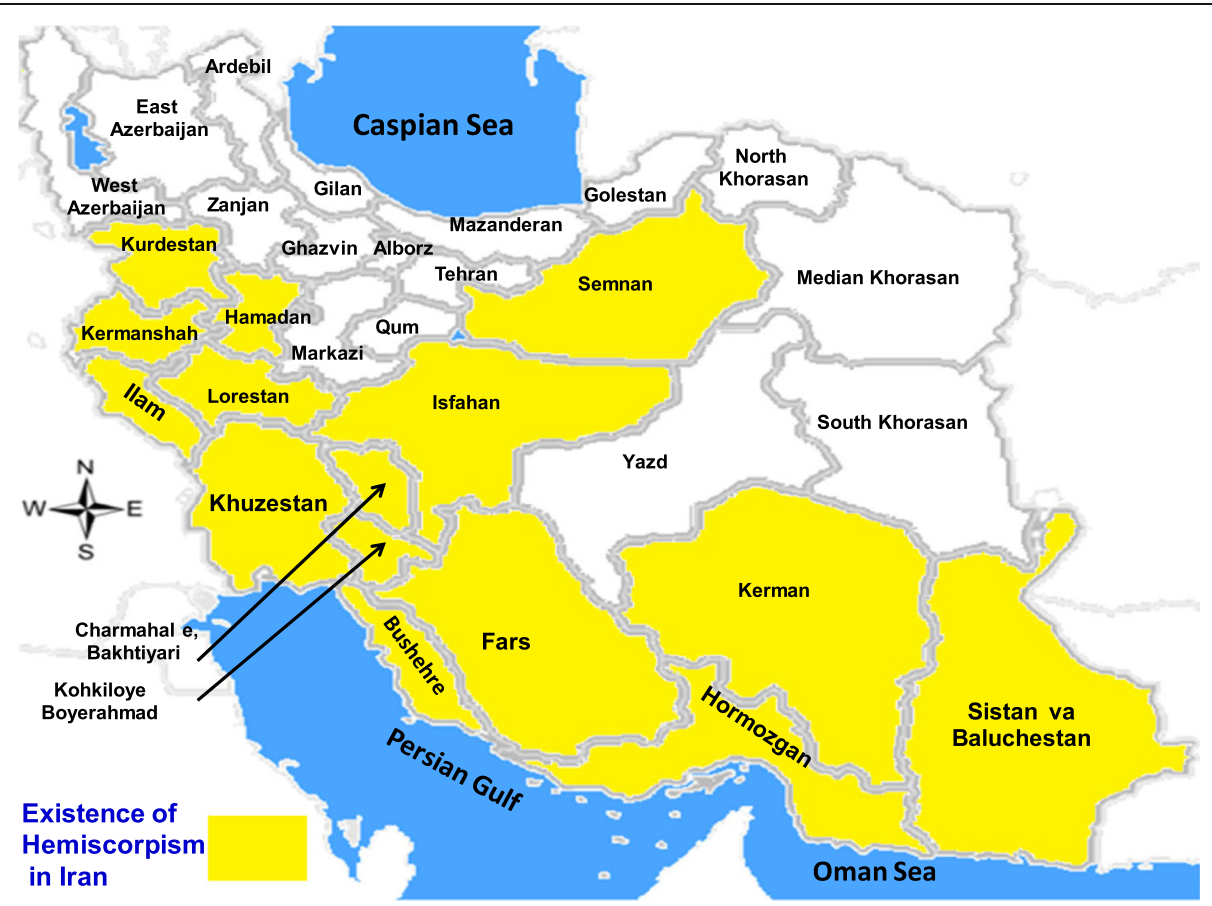

Fig. 2 Distribution of Hemiscorpius species in Iran (image prepared by R. Dehghani, reproduced with permission) 
The Academy of Gondishapur, also known as The Jondishapur University, was one of the three Sasanian centers of education and academy of learning in the city of Gundeshapur, Khuzestan Province, in Iran during late antiquity. It was considered the most important medical center of the ancient world during the 6th and 7th centuries. Since the capital of Iran during the Sassanian period was Ctesiphon or Mada'in, which was an area greatly affected by scorpionism by Hemiscorpius, numerous studies were carried out about this medical problem by researchers of the Academy of Gondishapur [50, 51].

The clinical manifestations of Hemiscorpius envenomation are quite infrequent, because its venom is one of the only presenting cytotoxic and hemolytic activities. Currently, the sting of Hemiscorpius species has been reported in several provinces of Iran, especially Khuzestan and Hormozgan, with significant clinical symptoms in victims, particularly children [52-56]. In traditional Iranian medicine, heating the sting site is one of the first measures. In the region of Rāmhormoz, people usually apply hot sand or hot stones immediately at the sting site $[48,49]$.

\section{The Hemiscorpius genus}

Hemiscurpius are non-digger scorpions usually the length of females and males reaches to 5 and $8 \mathrm{~cm}$, respectively (males have a longer tail). Therefore, they present sexual dimorphism and their body color is transparent to turbid yellow. The pedipalps and legs are lighter in color, while moveable and fixed fingers of pedipalps are reddish brown. Brown spots can be observed at the end of the

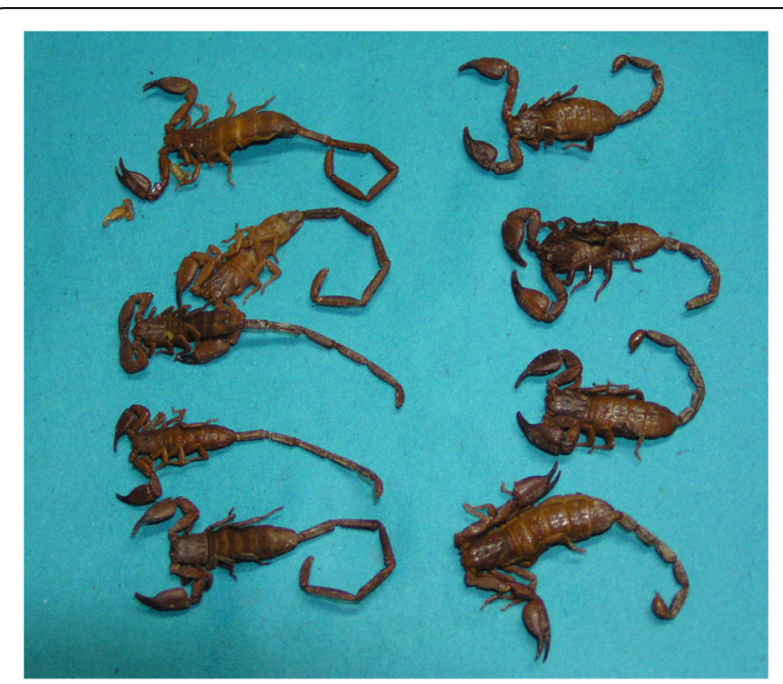

Fig. 3 A photographic illustration of males (on the left) and females (on the right) specimens of Hemiscorpius lepturus. Note the very short stinger size and longer tail in males (copyright by R. Dehghani, reproduced with permission) legs. The moving finger of chelicera have two branches (Fig. 3) [21, 22, 57].

$H$. lepturus venom is mainly composed of hemotoxins and cytotoxins [22]. A peptide isolated from $H$. lepturus venoms is hemicalcin, a calcium channel blocker that represents $0.6 \%$ of its crude venom. Intracerebroventricular injection of $300 \mathrm{ng}$ of hemicalcin in mice induces neurotoxic symptoms in vivo, followed by death [58]. Hemitoxin is a potassium channel inhibitor that represents about $0.1 \%$ of crude venom [59]. Likewise, heminecrolysin, with dermonecrotic activity, and hemilipin (phospholipase $\mathrm{A}_{2}$ ) inhibited angiogenesis both in vitro and in vivo [60-62].

One of the most abundant components of $H$. lepturus venom are the enzymes that play important roles in scorpion venoms. Different enzymes including phospholipases, metalloproteases, hyaluronidases and proteases were identified by transcriptome analysis in H. Lepturus venom. The ester bond of phospholipids, the most important component of the cell membrane is hydrolyzed by phospholipases. Whole components of $H$. lepturus venom were identified by analyzing the venom gland transcriptome of this Iranian scorpion [63].

\section{Scorpionism by Hemiscorpius Epidemiological data}

Scorpion stings are a major public health problem in south and southwestern Iran. Although scorpion stinga are reported in all provinces of the country, most cases occur in the provinces of Khuzestan, Hormozgan, Sistan and Baluchestan, Bushehr and Ilam [20].

The average incidence of scorpionism was estimated to be 59.5 cases per 1 hundred thousand inhabitants and 19.5 deaths take place annually in Iran [20]. However, some studies indicate that the real number of annual stings is much higher than that one officially reported $[64,65]$. Whereas the province of Mazandaran, in the northern region, has the lowest rate of cases (near zero), Khuzestan, in the southwest of Iran, has the highest one, reaching 541 cases per hundred thousand people [66].

Among the various species of scorpions in Iran, deaths are usually reported by stings of Androctonus crassicauda, $H$. lepturus and $H$. acanthocercus. The envenomation provoked by $H$. lepturus stings is significantly different from that one of the Buthidae family in severity and duration [21, 67]. The frequency of deaths caused by $H$. lepturus (Gadim) is higher [21, 67, 68].

Data collected during 5 years from two hospitals of the city of Ahvaz (center of Khuzestan) showed that $H$. lepturus was responsible for 10 to $15 \%$ of all hospital referred scorpion stings and $92 \%$ of all hospitalized victims of scorpion stings [21, 69].

Although scorpion stings were reported in southern and southwestern regions of Iran throughout the year, studies indicated that most stings happened in the warm 
months in spring and summer [15, 16, 21, 69-76]. A positive significant correlation between the frequency of scorpion stings and the environment temperature as well as the sunshine duration was reported [73]. However, the correlation between stings and relative humidity as a climate factor was negative [77].

Epidemiological analysis indicated that more than 50 to $60 \%$ of patients were from urban regions $[15,21,69,72$, $76,78]$. Some studies conducted on age and sex distribution of scorpionism by Hemiscorpius indicated that most patients were female $[71,75,78]$. Other works, nevertheless, revealed that men were more at risk of scorpion stings than women [15, 66, 70, 72, 74]. Contrarily, a few studies reported that the frequency of recorded scorpion stings in both genders was nearly similar and there was not any significant difference between male and female in all age groups [16, 21, 69, 79]. Another observation was that women were more stung by scorpions in indoor places, whereas men were more at risk in the outdoors [77].

According to some findings, children were at greatest risk of scorpionism by Hemiscorpius. Envenomation is usually more severe in children and the mortality is higher among them $[78,80]$. Research indicates that children under 10 years old and young people (aged between 10 and 20 years) were the first and second age groups, respectively, more at risk of scorpionism by Hemiscorpius in Iran $[21,69,78,81]$.

Most scorpion stings affect the lower part of the body (legs) [21, 71, 72]. However, other sting sites included the trunk, hands, head and neck [21]. Stings occurred mainly at night from 7 p.m. to 5 a.m. and in the early morning from 5 to 12 a.m. [21, 69].

The time interval observed between Gadim stings and antivenom treatment was less than $6 \mathrm{~h}$ for $56.6 \%$ of the cases, 6 to $12 \mathrm{~h}$ for $21 \%$ of cases, more than $12 \mathrm{~h}$ for $11 \%$ of cases and the rest of the victims did not received any antivenom [66]. A single study showed that the average time interval was less than $4 \mathrm{~h}$ for more than $70 \%$ of the hospitalized patients [21].

\section{Clinical dato}

Scorpionism by Hemiscorpius may affect vital organs, with deadly consequences. The length of hospitalization of affected patients is greater than the that of patients stung by any other species in Iran. The delayed effects of the venom and its retention in the body are the main reasons for this phenomenon $[81,82]$.

Local symptoms It has been reported that $H$. lepturus stings on the body are not easily recognized because of their small size (about $1 \mathrm{~mm}$ long). In comparison, black scorpion (A. crassicauda) stings that have about 6 to $8 \mathrm{~mm}$ are easily found [14, 81]. Since local pain due to $H$. lepturus stings is minimal, patients usually do not complain and do not seek medical help until the toxicity has already been established. The initial symptoms only include a minor itching at the sting site and mild pain. Therefore, local manifestations $24 \mathrm{~h}$ after the sting may be considered negligible. Buthidae stings, on the other hand, such as those by Odonthobuthus doriae, are more painful in the first moments. Symptoms such as local redness, inflammation, gangrene, necrosis, ecchymosis and blisters appears about $24 \mathrm{~h}$ after $H$. lepturus stings [83-85]. Consequently, some patients look for medical aid after a few days, when the sting site is inflamed and painful. Over time, the venom penetrates the dermis and adjacent tissues and causes cellulite and severe inflammation. An intense pain and cellulitis in the sting area may be seen. The most important consequences of Hemiscorpius stings, especially in children, are local necrosis, swelling, erythema and ecchymosis $[21,22,69,81,86]$.

If the scorpion stinger passes though the epidermis and reaches capillaries and lymph system, then the effects of venom will be more severe. In some of these cases, venom may reach blood and lymph systems, causing non-uniform ecchymosis patches. The diameter of this non-uniform ecchymosis is about $25 \mathrm{~cm}$, but sometimes does not lead to gangrenous cellulitis and sore. In these patients, systemic symptoms are rare and ecchymosis after one or 2 weeks, by itself without any action, will be improved [22, 87, 88]. Gadim scorpion venom caused skin sore or necrotic areas with 20-25 mm diameter in experimental rats. It was reported that any systemic problem was not found and animals remained alive [53, 89]. In children, stings on the hands and feet lead to severe swelling and inflammation due to the soft thin tissue of these areas. Stings on the neck, face and body in children and adult patients often are followed by more cellulite and swelling and they may be more dangerous in terms of sting site. After a while, the surface area of gangrene is cut out and sores appear through the fatty tissue under the skin $[20,22]$. Extensive wounds only heal with skin grafts. It seems that in people or laboratory animals that have severe allergic reactions, the venom movement is stopped due to ulcers and necrosis. This means that the immune system with severe skin inflammation prevents blood and oxygen from reaching the sting site, except at the injection area [20,88].

Systemic effects Cardiotoxic effects of $H$. leptorus envenomation in humans have been reported. However, studies on the envenomation by this scorpion revealed that there are arrhythmogenic and negative inotropic effects in animal models [56]. Gadim venom has significant effects on white blood cells and, therefore, causes erythematous rashes and petechial hemorrhagic into the skin $[90,91]$. Scorpion venoms, especially the one from Gadim, have also demonstrated hemolytic activity in vitro and it 
has been observed that the larger the amount of venom, the greater the extension of hemolytic damage [92, 93]. Patients stung by Gadim, especially children, can report these symptoms, but they are usually mild in adults and their effects may continue for 2 to 3 weeks without treatment $[86,94]$. Among children, Gadim venom provokes a significant reduction in hematocrit rates [79].

Acute kidney injury (AKI) is frequently observed in children stung by $H$. lepturus. It was reported that for young patients, the delay in receiving medical care may result in pigmenturia, microangiopathic hemolysis, anemia, proteinuria and pyuria, which are predictors for AKI in children. Hemoglobinuria was found in more than $50 \%$ of $H$. lepturus sting cases. Hemolytic uremic syndrome after $H$. lepturus sting has also been reported [55, 79, 86, 95-99].

Hemoglobinuria, coagulopathy, transfusion and kidney problems were more observed in patients who had been admitted to the hospital after $24 \mathrm{~h}$ following the sting. Kidney problems were present only in patients with blood cell lysis and hemoglobinuria. The rates of hemoglobinuria were $93.8 \%$ in H. lepturus stung children [81]. Delayed hospital admission was recorded in cases of death. Therefore, clinical manifestations following $H$. lepturus envenomation including late renal failure are mainly time-dependent [24, 100]. Death due to $H$. lepturus envenomation may be provoked by cardiovascular or renal failure [83].

Overall, general signs such as seizures, distraction, irritability, restlessness, nausea, vomiting, headache, and possibly cyanosis have central nervous origin. These symptoms indicate the severity of envenomed patients. The central nervous system manifestations are seen mainly among children victims. Mental disorders as restlessness, distractibility, delusions and inappropriate behavior appears and usually return to normal as the patient improves. However, some patients, even after recovery, suffer from mental disorders such as increased aggressiveness, irritability, depression and emotional imbalance for longer periods [18, 21, 22, 69, 83].

It has been reported that the main clinical signs of $H$. lepturus envenomation are similar to those caused by spider bites of the genus Loxosceles (L. reclusa and $L$. intermedia). Loxoscelism is the only proven arachnological cause of dermonecrosis in the Western Hemisphere, particularly in the tropical urban regions of South America. There are many similarities in the toxic manifestations of the venom from this spider and the venom from $H$. lepturus in terms of the dermonecrosis, nephrotoxicity and direct hemolytic activities. Hemolysis causing loss of approximately $15 \%$ of the blood volume within $72 \mathrm{~h}$ [21, $62,69,81,101-112]$.

\section{Serotherapy with antivenom}

Over the last 30 years, the most frequently used approach in the treatment of scorpionism in Iran is serotherapy with multivalent antivenom against six common Iranian scorpions [113]. The multivalent scorpion antivenom is presented as $5-\mathrm{mL}$ ampoules of a pepsin digested refined and concentrated preparation, obtained from equine hyperimmune serum, stored at 2 to $8{ }^{\circ} \mathrm{C}$. This antivenom is produced by Razi Institute of Vaccine and Serum Production in Karaj, Iran. It has specific potency against the venoms of the six endemic Iranian scorpions (Androctonus crassicauda, Buthotus saulcyi, Buthotus schach, Odontobuthus doriae, Mesobuthus eupeus and H. lepturus) [113].

Currently in Iran, stung patients, including those stung by $H$. lepturus, are treated in most clinical centers with intramuscular injection of available multivalent scorpion antivenom [93]. It has been reported that more than $95 \%$ of scorpion sting patients received the polyvalent antivenom. Despite the immediate administration of one or two doses of polyvalent antivenom intramuscularly at the hospital, in some severe cases, signs and symptoms have been observed. This may be due to the elapsed time between sting and treatment or improper dosage [93]. It is known that the efficacy of antivenom for reversal of cytotoxic manifestations following envenomation is time-limited. Therefore, using antivenom as early as possible before the occurrence of cytotoxic effects on different organs is recommended [114]. The time of antivenom injection has an important role in the effectiveness of antivenom. The epidemiological data and results of studies on experimental animals showed that the chance of preventing the occurrence and progress of systemic signs increases significantly when antivenom is administrated early. If any systemic signs or symptoms are observed in victims, it is recommended the intravenous administration of antivenom [115-117].

\section{Conclusion}

The general results of this literature review indicate that the toxicity of $H$. lepturus stings differ from other Iranian scorpion stings in relation to duration and severity. Even the sting of this scorpion is without acute pain. Scorpionism by Hemiscorpius may related to several species, not only $H$. lepturus. Hence, recognizing the species involved in an envenomation case is more important. Hemiscorpius species are morphologically very close to each other. Misidentification may induce great mistakes in the final interpretation of results, which can only lead to more inefficacy in the treatment of disorders caused by dangerous scorpion species $[41,118]$.

Clinical symptoms and mortality from scorpion stings are related to two main factors: the characteristics of the stung patient (such as age and health condition) and the characteristics of the scorpion (such as species and venom potency) [77, 119, 120]. Scorpionism by Hemiscorpius is an important public health issue in Iran, 
especially in urban areas of the southwest and south regions. It is more prevalent in children and young people, whereas the mortality is greater in children. Most cases are recorded in the warm months of spring and summer at night. The dermal symptoms and systemic manifestations caused by $H$. lepturus indicates that venom of this species is mixture of toxins that is differs from the other Iranian scorpion species. H. lepturus venom is primarily a cytotoxic agent and has hemolytic, nephrotoxic and to some extent hepatotoxic activities.

The use of polyvalent antivenom to prevent different symptoms in scorpionism is recommended. According to evidence, the cardiovascular manifestations of stung patients, who received antivenom as soon as possible, were mild and the hemoglobinuria and renal failure were delayed as well [121, 122].

The high incidence of scorpionism by Hemiscorpius in Iran, especially in Khuzestan, suggests the necessity of preventive programs for decreasing the incidence of this phenomenon. One of the main challenges of controlling scorpionism is promotion of effective participation and awareness among the population. A well-planned health education program might be useful in preventing stings. Promoting health education, mainly among groups who are more at risk, about preventive measures against scorpions integrated with environmental measures and sanitary education of communities should be goal of control campaigns.

\section{Acknowledgements}

The authors highly appreciate the assistance and collaboration of the laboratory staff of the Social Determinants of Health (SDH) Research Center and Department of Environment Health, Kashan University of Medical Sciences.

\section{Funding}

Not applicable.

\section{Authors' contributions}

MM was responsible for collecting data. RD designed the study and analyzed the selected studies. FK was a major contributor in writing the manuscript. All authors read and approved the final manuscript.

\section{Ethics approval and consent to participate}

Not applicable.

\section{Consent for publication}

Not applicable.

\section{Competing interests}

The authors declare that they have no competing interests.

\section{Publisher's Note}

Springer Nature remains neutral with regard to jurisdictional claims in published maps and institutional affiliations.

\section{Author details}

${ }^{1}$ Social Determinants of Health (SDH) Research Center and Department of Environment Health, Kashan University of Medical Sciences, Kashan, Iran.

${ }^{2}$ Faculty of Health, Kerman University of Medical Sciences, Kerman, Iran.
Received: 4 August 2017 Accepted: 14 February 2018

Published online: 02 March 2018

\section{References}

1. Dehghani R, Sharif A, Madani M, Kashani HH, Sharif MR. Factors influencing animal bites in Iran: a descriptive study. Osong Public Health Res Perspect. 2016:7(4):273-7.

2. Dehghani R, Rastegar Pouyani N, Dadpour B, Keyler D, Panjehshahi M, Jazayeri $M$, et al. A survey on non-venomous snakes in Kashan (Central Iran). J Biol Today's World. 2016;5(4):65-75.

3. Dehghani R, Sharif MR, Moniri R, Sharif A, Haddad Kashani H. The identification of bacterial flora in oral cavity of snakes. Comp Clin Pathol. 2016:25(2):279-83.

4. Dehghani R, Sharif A, Assadi MA, Haddad Kashani H, Sharif MR. Fungal flora in the mouth of venomous and non-venomous snakes. Comp Clin Pathol. 2016;25(6):1207-11.

5. Huang LW, Wang JD, Huang JA, Hu SY, Wang LM, Tsan YT. Wound infections secondary to snakebite in central Taiwan. J Venom Anim Toxins Incl Trop Dis. 2012;18(3):272-6. http://www.scielo.br/scielo.php?script=sci_ arttext\&pid=S1678-91992012000300004

6. Fonseca MG, Moreira WMQ, Cunha KC, Ribeiro ACMG, Almeida MTG. Oral microbiota of Brazilian captive snakes. J Venom Anim Toxins Incl Trop Dis. 2009;15(1):54-60. http://www.scielo.br/scielo.php?script=sci_arttext\&pid= S1678-91992009000100006.

7. Dehghani R, Mehrpour O, Shahi MP, Jazayeri M, Karrari P, Keyler D, et al. Epidemiology of venomous and semi-venomous snakebites (Ophidia: Viperidae, Colubridae) in the Kashan city of the Isfahan province in Central Iran. J Res Med Sci. 2014;19(1):33-40.

8. Dehghani R, Fathi B, Shahi MP, Jazayeri M. Ten years of snakebites in Iran. Toxicon. 2014:90:291-8.

9. Yousef Mogaddam M, Dehghani R, Enayati AA, Fazeli-Dinan M, Motevalli HF. Epidemiology of scorpionism in Darmian, Iran, 2015. J Mazandaran Univ Med Sci. 2016:26(141):131-6. [in Persian, abstract in English]

10. Dehghani R, Valizade R, Mahmoodi S. A review of the scorpion predators and the introduction of Scarites subterraneus, as a new predatory of them in Iran. J Entomol Res. 2016;40(3):291-6.

11. Yousef Mogaddam M, Dehghani R, Enayati AA, Fazeli-Dinan M, Vazirianzadeh B, Yazdani-Cherati J, et al. Scorpion fauna (Arachnida: Scorpiones) in Darmian county, Iran (2015-2016). J Mazandaran Univ Med Sci. 2017;26(144):108-18. [in Persian, abstract in English]

12. Dehghani R, Vazirianzadeh B, Rahimi Nasrabadi M, Moravvej SA. Study of scorpionism in Kashan in central Iran. Pak J Med Sci. 2010;26(4):955-8.

13. Kassiri H, Kasiri A, Kasiri E, Abdian P, Matori F, Lotfi M. Epidemiological characteristics and incidence rate of definite scorpion stings in Mahshahr County, Iran: multivariate analysis of 1635 cases. Asian Pac J Trop Dis. 2015; 5(1):80-4.

14. Radmanesh M. Androctonus crassicauda sting and its clinical study in Iran. J Trop Med Hyg. 1990;93(5):323-6.

15. Kassiri H, Kasiri A, Kasiri E, Safarpor S, Lotfi MA. Hospital-based study on scorpionism in Khorram-shahr County, southwestern Iran. Asian J Epidemiol. 2014;7(2):28-35.

16. Shahbazzadeh D, Amirkhani A, Djadid ND, Bigdeli S, Akbari A, Ahari H, et al. Epidemiological and clinical survey of scorpionism in Khuzestan province, Iran (2003). Toxicon. 2009;53(4):454-9.

17. Moosavy SH, Shahi M, Rafinejad J, Zare S, Madani A, Navidpour S. Epidemiological aspect of scorpion sting in Bandar Abbas, Iran, during 2009-2011. Electron Physician. 2016;8(4):2286-90.

18. Jalali A, Rahim F. Epidemiological review of scorpion envenomation in Iran. Iran J Pharm Res. 2014:13(3):743-56.

19. Dehghani R, Djadid ND, Shahbazzadeh D, Bigdelli S. Introducing Compsobuthus matthiesseni (Birula, 1905) scorpion as one of the major stinging scorpions in Khuzestan, Iran. Toxicon. 2009;54(3):272-5.

20. Dehghani R, Fathi B. Scorpion sting in Iran: a review. Toxicon. 2012;60(5): 919-33.

21. Pipelzadeh $\mathbf{M H}$, Jalali A, Taraz M, Pourabbas R, Zaremirakabadi A. An epidemiological and a clinical study on scorpionism by the Iranian scorpion Hemiscorpius lepturus. Toxicon. 2007;50(7):984-92.

22. Radmanesh M. Cutaneous manifestations of the Hemiscorpius lepturus sting: a clinical study. Int J Dermatol. 1998;37(7):500-7.

23. Lowe G. Two new Hemiscorpius Peters, 1861 (Scorpiones: Hemiscorpiidae) from northern Oman. Euscorpius. 2010;2010(91):1-24. 
24. Soleglad ME, Fet $V$, Kovarík F. The systematic position of the scorpion genera Heteroscorpion Birula, 1903 and Urodacus Peters, 1861 (Scorpiones: Scorpionoidea). Euscorpius. 2005;20:1-37.

25. Prendini L. Phylogeny and classification of the superfamily Scorpionoidea Latreille 1802 (Chelicerata, Scorpiones): an exemplar approach. Cladistics. 2000;16(1):1-78

26. Prendini L, Wheeler WC. Scorpion higher phylogeny and classification, taxonomic anarchy, and standards for peer review in online publishing. Cladistics. 2005;21(5):446-94.

27. Soleglad ME, Fet V. High-level systematics and phylogeny of the extant scorpions (scorpions: Orthosterni). Euscorpius. 2003;2003(11):1-175.

28. Order PL, Scorpiones CL. Koch, 1850. In: Zhang ZQ, editor. Animal biodiversity: an outline of higher-level classification and survey of taxonomic richness. Auckland: Ed. Zootaxa; 2011. p. 115-77.

29. Santibáñez-López CE, Francke OF, Ureta C, Possani LD. Scorpions from Mexico: from species diversity to venom complexity. Toxins (Basel). 2015; 8(1):E2. https://doi.org/10.3390/toxins8010002.

30. Rein JO. The scorpion files. Trondheim: Norwegian University of Science and Technology. Available online: http://www.ntnu.no/ub/scorpion-files/. Accessed 21 Mar 2017.

31. Soleglad ME, Fet V. Contributions to scorpion systematics. III. Subfamilies Smeringurinae and Syntropinae (Scorpiones: Vaejovidae). Euscorpius. 2008; 2008(71):1-115.

32. Dehghani R, Kassiri H. Geographical distribution of scorpion Odontobuthus doriae in Isfahan Province, Central Iran. J Arthropod-borne Dis. 2017;11(3):433.

33. Ahmadimarzale M, Sabuhi H, Sabahi Bidgoli M, Dehghani R, Hoseindoost G, Mesgari L. Study of scorpion species abundance in cities Aran \& Bidgol and Kashan, Isfahan, Iran. J Ent Res. 2017;41(3):337-42.

34. Karataş A, Gharkheloo MM. A new Hemiscorpius Peters, 1861 (Scorpiones: Hemiscorpiidae) from southwestern Iran. Turk J Zool. 2013;37(1):15-23.

35. Dehghani R, Haghi FM, Mogaddam MY, Sedaghat MM, Hajati H. Review study of scorpion classification in Iran. J Entomol Zool Stud. 2016:4(5):440-4.

36. Shahi M, Mousavi SH, Navidpour SS, Rafinejad J. A review study on distribution and medical importance of Hemiscorpius Peters, 1861 in Iran. J Mazandaran Univ Med Sci. 2015;24(120):107-24. [in Persian, abstract in English]

37. Al-Asmari AK, Al-Saief AA, Abdo NM, Al-Moutaery KR. New additions to the scorpion fauna of Riyadh region, Saudi Arabia. J Venom Anim Toxins inc Trop Dis. 2009;15(4):612-32. http://www.scielo.br/scielo.php?script=sci_ arttext\&pid=S1678-91992009000400003.

38. Bawaskar HS, Bawaskar PH. Scorpion sting: update. J Assoc Physicians India. 2012;60:46-55.

39. Lourenco WR. The scorpion families and their geographical distribution. J Venom Anim Toxins. 2001;7(1):03-23. http://www.scielo.br/scielo. php?script=sci_arttext\&pid=S0104-79302001000100002

40. Lourenço WR. More about the African species of Hemiscorpius Peters, 1861 (Scorpiones: Hemiscorpiidae), and description of a new species from Egypt. Boletín de la SEA. 2011:49:23-6.

41. Monod L, Lourenço WR. Hemiscorpiidae (Scorpiones) from Iran, with descriptions of two new species and notes on biogeography and phylogenetic relationships. Rev Suisse Zool. 2005;112(4):869-941.

42. Nazari M, Hajizadeh MA. Faunistic study on scorpions and the epidemiology of scorpionism in bam, southeast of Iran. Glob J Health Sci. 2017:9(2):177-83.

43. Kassiri H, Teimouri A, Shemshad M, Sharifinia N, Shemshad K. Epidemiological survey and clinical presentation on scorpionism in southwest of Iran. Middle-East J Sci Res. 2012;12(3):325-30.

44. Motevalli Haghi F, Dehghani R. A review of scorpions reported in Iran. J Mazandaran Univ Med Sci. 2017;27(151):213-26. [in Persian]

45. Dehghani R, Moabed Mehdi Abadi SH, Kamyabi F, Haghdoost AA, Mashayekhi M, Soltani H. Scorpion fauna of Kerman province, Iran. J Kerman Uni Med Sci. 2008;15(2):172-81. [in Persian]

46. Mozaffari E, Sedaghat MM, Sanei-Dehkordi A, Akbarzadeh K. Biodiversity and species composition of scorpions (Arachnida, Scorpiones) in llam County, Iran. J Appl Sci Res. 2013:9(9):5412-8.

47. Dehghani R, Rafinejad J, Fathi B, Panjeh-Shahi M, Jazayeri M, Hashemi A. A retrospective study on scorpionism in Iran (2002-2011). J Arthropod Borne Dis. 2017;11(2):194-203.

48. Dehghani $\mathrm{R}$, Arani MG. Scorpion sting prevention and treatment in ancient Iran. J Tradit Complement Med. 2015;5(2):75-80.

49. Avicenna $\mathrm{H}$. Sting and bite of insidious insects. In: Avicenna $\mathrm{H}_{\text {, editor. The }}$ canon of medicine. 2nd ed. Tehran: Soroush Publications; 1991. p. 43-52.
50. Najmabadi M. Mohammad-ibn-Zakaria Razi, physician, philosopher, and Iranian chemist, vol. 1. 2nd ed. Tehran: Razi University Publications; 1992. p. 66-112.

51. Najmabadi M. Venom and poison. In: Najmabadi M, editor. History of medicine in Iran. 2nd ed. Tehran University Publications: Tehran; 1992. p. 246-8.

52. Hedaiaty $M$, Hedaiaty $M$, Salimi R. The injuries and inflammation induced by the venom of the Iranian scorpions. J Inj Inflamm. 2016;1(1):e06.

53. Heidarpour M, Ennaifer E, Ahari H, Srairi-Abid N, Borchani L, Khalili G, et al. Histopathological changes induced by Hemiscorpius lepturus scorpion venom in mice. Toxicon. 2012;59(3):373-8.

54. Emam SJ, Khosravi AD, Alemohammad A. Evaluation of hematological and urine parameters in Hemiscorpius lepturus (Gadim) victims referred to Razi Hospital, Ahwaz, Iran. J Med Sci. 2008;8:306-9.

55. Zare Mirakabbadi A, Zolfagharian H, Hedayat A, Jalali A. Clinical and biochemical manifestation produced by scorpion (Hemiscorpius lepturus) venom in experimental animals. J Venom Anim Toxins Incl Trop Dis. 2007: 13(4):758-65. http://www.scielo.br/scielo.php?script=sci_arttext\&pid=S167891992007000400007

56. Pourkhalili K, Kim E, Mashayekhy NR, Kamyab M, Hoseiny SM, Evazy R, et al. Cardiotoxic and arrhythmogenic effects of Hemiscorpius lepturus scorpion venom in rats. J Arthropod Borne Dis. 2015;9(2):215-25.

57. Dehghani $R$, Khamehchian T, Miranzadeh MB. Surveying on the biologic behaviors of Hemiscorpius lepturus Peters 1861, scorpion in laboratory (Khuzestan, Iran) (scorpions: Hemiscorpiidae). Pak J Biol Sci. 2007:10(18): 3097-102.

58. Shahbazzadeh D, Srairi-Abid N, Feng W, Ram N, Borchini L, Ronjat M, et al Hemicalcin, a new toxin from the Iranian scorpion Hemiscorpius lepturus which is active on ryanodine-sensitive Ca2+ channels. Biochem J. 2007; 404(1):89-96.

59. Srairi-Abid N, Shahbazzadeh D, Chatti I, Mlayah-Bellalouna S, Mejdoub H, Borchani L, et al. Hemitoxin, the first potassium channel toxin from the venom of the Iranian scorpion Hemiscorpius lepturus. FEBS J. 2008;275(18): 4641-50.

60. Borchani L, Sassi A, Gharsa HB, Safra I, Shahbazzadeh D, Ben Lasfar Z, et al. The pathological effects of Heminecrolysin, a dermonecrotic toxin from Hemiscorpius lepturus scorpion venom are mediated through its lysophospholipase D activity. Toxicon. 2013:68:30-9.

61. Borchani L, Sassi A, Shahbazzadeh D, Strub JM, Tounsi-Guetteti H, Boubaker MS, et al. Heminecrolysin, the first hemolytic dermonecrotic toxin purified from scorpion venom. Toxicon. 2011;58(1):130-9.

62. Jridi I, Catacchio I, Majdoub H, Shahbazeddah D, El Ayeb M, Frassanito MA, et al. Hemilipin, a novel Hemiscorpius lepturus venom heterodimeric phospholipase A2, which inhibits angiogenesis in vitro and in vivo. Toxicon. 2015:105:34-44.

63. Kazemi-Lomedasht F, Khalaj V, Pooshang Bagheri K, Behdani M, Shahbazzadeh D. The first report on transcriptome analysis of the venom gland of Iranian scorpion, Hemiscorpius lepturus. Toxicon. 2017;125:123-30.

64. Dehghani $\mathrm{R}$, Valaie $\mathrm{N}$. The review of status of scorpion sting in Iran and problems from it. FEYZ. 2005;9(33):73-92. [In Persian, abstract in English]

65. Rafiazadeh S. Report of scorpion sting in Iran during 2009. Center of Management of Preventing and Control the Diseases; 2009. p. 1-15. [in Persian]

66. Rafizadeh S, Rafinejad J, Rassi Y. Epidemiology of scorpionism in Iran during 2009. J Arthropod Borne Dis. 2013;7(1):66-70.

67. Sanaei-Zadeh H. Painless stings of yellow Iranian scorpions. Iran Red Crescent Med J. 2017;19(4):e42645.

68. Nejati J, Mozafari E, Saghafipour A, Kiyani M. Scorpion fauna and epidemiological aspects of scorpionism in southeastern Iran. Asian Pac J Trop Biomed. 2014;4(Suppl 1):S217-21.

69. Jalali A, Pipelzadeh MH, Sayedian R, Rowan EG. A review of epidemiological, clinical and in vitro physiological studies of envenomation by the scorpion Hemiscorpius lepturus (Hemiscorpiidae) in Iran. Toxicon. 2010;55(2-3):173-9.

70. Kassiri H, Feizhaddad MH, Abdehpanah M. Morbidity, surveillance and epidemiology of scorpion sting, cutaneous leishmaniasis and pediculosis capitis in Bandar-mahshahr County, southwestern Iran. J Acute Dis. 2014; 3(3):194-200.

71. Mohseni A, Vazirianzadeh B, Hossienzadeh M, Salehcheh M, Moradi A, Moravvej SA. The roles of some scorpions, Hemiscorpius lepturus and Androctonus crassicauda, in a scorpionism focus in Ramhormorz, southwestern Iran. J Insect Sci. 2013;13:89. https://doi.org/10.1673/031.013.8901.

72. Kassiri H, Kasiri E, Veys-Behbahani R, Kasiri A. Epidemiological survey on scorpionism in Gotvand County, southwestern Iran: an analysis of 1067 patients. J Acute Dis. 2014;2014:314-9. 
73. Taj SH, Vazirian M, Vazirianzadeh B, Bigdeli SH, Salehzadeh Z. Effects of climatological variables on scorpion sting incidence in Ramshir area southwest of Iran. J Exp Zool India. 2012;15(2):575-7.

74. Sagheb MM, Sharifian M, Moini M, Sharifian AH. Scorpion bite prevalence and complications: report from a referral centre in southern Iran. Trop Dr. 2012:42(2):90-1.

75. Kassiri H, Mohammadzadeh Mahijan N, Hasanvand Z, Shemshad M, Kh S Epidemiological survey on scorpion sting envenomation in south-west, Iran. Zahedan J Res Med Sci. 2012;14(8):80-3.

76. Kassiri H, Kasiri A, Fardin-Mohammadjani M. A cross-sectional study on scorpionism in Masjed Soleyman county, southwestern Iran. J Entomol. 2014;11(4):238-47.

77. Ebrahimi V, Hamdami E, Moemenbellah-Fard MD, Ezzatzadegan Jahromi S. Predictive determinants of scorpion stings in a tropical zone of south Iran: use of mixed seasonal autoregressive moving average model. J Venom Anim Toxins Incl Trop Dis. 2017;23:39. https://doi.org/10.1186/s40409-017-0129-4.

78. Vazirianzadeh B, Nourmandi Pour S, Hashemi Shahraki A, Dehghani R, Amraee K. A study on some epidemiologic parameters among scorpion stung people who referred to Sirjan health center, Kerman province of Iran in 2007-2009. Jentashapir. 2012;3(4):539-43. [in Persian]

79. Vazirianzadeh B, Maraghi S, Samie M, Vazirianzadeh M, Montazeri MR, Eghbalnejad Mofrad AM. Evaluating some medical lab parameters among hospitalized children in Khuzestan following scorpion sting, SW Iran. IJSS. 2017:5(3):91-6

80. Chippaux JP, Goyffon M. Epidemiology of scorpionism: a global appraisal. Acta Trop. 2008;107(2):71-9.

81. Pipelzadeh MH, Dezfulian AR, Jalali MT, Mansouri AK. In vitro and in vivo studies on some toxic effects of the venom from Hemiscorpius lepturus scorpion. Toxicon. 2006;48(1):93-103.

82. Shahi M, Rafinejad J, Az-Khosravi L, Moosavy SH. First report of death due to Hemiscorpius acanthocercus envenomation in Iran: case report. Electron Physician. 2015;7(5):1234-8.

83. Radmanesh M. Clinical study of Hemiscorpion lepturus in Iran. J Trop Med Hyg. 1990;93(5):327-32

84. Dehghani R, Khamehchian T. Scrotum injury by scorpion sting. J Arthropod Borne Dis. 2008:2(1):49-52.

85. Razi E, Malekanrad E. Asymmetric pulmonary edema after scorpion sting: a case report. Rev Inst Med Trop Sao Paulo. 2008:50(6):347-50.

86. Sanaei-Zadeh H, Marashi SM, Dehghani R. Epidemiological and clinical characteristics of scorpionism in shiraz (2012-2016); development of a clinical severity grading for Iranian scorpion envenomation. Med J Islam Repub Iran (MJIRI). 2017;31(1):158-66.

87. Paknahad A, Pouraskar M, Pour AG. A review of scorpion stings in Iran. J Curr Res Sci. 2014;2(6):887-90.

88. Zare MA. Hemiscorpius lepturus envenomation: manifestations and management with specific antivenom. Arch Razi Inst. 2013;68(2):91-9.

89. Dehghani $R$, Khamechian $T$, Vazirianzadeh $B$, Moravvej $A$. Toxic effects of scorpion, Hemiscorpius lepturus (Hemiscorpiidae) venom on mice. J Anim. Plant Sci. 2012:22(3):593-6.

90. Ghafourian M, Ganjalikhanhakemi N, Hemmati AA, Dehghani R, Kooti W. The effect of Hemiscorpius lepturus (Scorpionida: Hemiscorpiidae) venom on leukocytes and the leukocyte subgroups in peripheral blood of rat. $J$ Arthropod Borne Dis. 2016;10(2):159-67.

91. Shayesteh AA, Zamiri N, Peymani P, Zargani FJ, Lankarani KB. A novel management method for disseminated intravascular coagulation like syndrome after a sting of Hemiscorpius lepturus: a case series. Trop Biomed. 2011;28(3):518-23.

92. Salimian J, Zargan J, Ebrahimi F, Farahmandzad A, Hajibeygi A. Role of Hemiscorpius lepturus venom on red blood cell fragility. Kowsar Med J. 2002; 7(3):185-90

93. Rahmani $\mathrm{AH}$, Jalali $\mathrm{A}$. Symptom patterns in adult patients stung by scorpions with emphasis on coagulopathy and hemoglubinuria. J Venom Anim Toxins incl Trop Dis. 2012;18(4):427-31. http://www.scielo.br/scielo. php?script=sci_arttext\&pid=\$1678-91992012000400011.

94. Valavi E, Ansari MJA. Hemolytic uremic syndrome following Hemiscorpius lepturus (scorpion) sting. Indian J Nephrol. 2008;18(4):166-8.

95. Valavi E, Amuri P, Ahmadzadeh A, Cheraghian B, Ahankoob E. Acute kidney injury in Hemiscorpius lepturus scorpion stung children: risk factors and clinical features. Saudi J Kidney Dis Transpl. 2016;27(5):936-41.

96. Malhotra KK, Mirdehghan CM, Tandon HD. Acute renal failure following scorpion sting. Am J Trop Med Hyg. 1978;27(3):623-6.
97. de Sousa Alves R, do Nascimento NR, Barbosa PS, Kerntopf MRLM, de Sousa CM, Martins RD. Renal effects and vascular reactivity induced by Tityus serrulatus venom. Toxicon. 2005;46(3):271-6.

98. Silva NA, Albuquerque CMR, Marinho AD, Jorge RJB, Silva Neto AG, Monteiro HAS, et al. Effects of Tityus stigmurus (Thorell 1876) (Scorpiones: Buthidae) venom in isolated perfused rat kidneys. An Acad Bras Ciênc. 2016; 88(1):665-75.

99. Valavi E, Ansari MJ, Hoseini S. ADAMTS-13 deficiency following Hemiscorpius lepturus scorpion sting. Saudi J Kidney Dis Transpl. 2011;22(4):792-5.

100. Mostafazadeh B, Gorbani A, Mogaddaspour M, Khoddami Vishteh HR. The effect of plasmapheresis on treating disseminated intravascular coagulation (DIC) caused by a Hemiscorpius lepturus (Gadim) sting. Clin Toxicol. 2017;55(8):902-7.

101. Torabi E, Behdani M, Hosseininejad Chafi M, Moazzami R, Sabatier JM, Khalaj $\checkmark$, et al. Characteristics and lethality of a novel recombinant dermonecrotic venom phospholipase D from Hemiscorpius lepturus. Toxins (Basel). 2017; 9(3):102. https://doi.org/10.3390/toxins9030102.

102. Da Silva PH, Da Silveira RB, Appel MH, Mangili OC, Gremski W, Veiga SS Brown spiders and loxoscelism. Toxicon. 2004;44(7):693-709.

103. Hogan CJ, Barbaro KC, Winkel K. Loxoscelism: old obstacles, new directions. Ann Emerg Med. 2004;44(6):608-24.

104. Swanson DL, Vetter RS. Loxoscelism. Clin Dermatol. 2006:24(3):213-21.

105. Wasserman GS, Calcara DA, Green JA, Stoecker WV, Larkin K. Systemic loxoscelism confirmation by bite-site skin surface ELISA. Mo Med. 2009; 106(6):425-31.

106. Algren DA, Lowry JA, Wasserman GS. Pearls about loxoscelism. Ann Emerg Med. 2011;57(4):419-20.

107. Michaud ME, Gibler WB. Hemolytic anemia and hemoglobinuria due to systemic loxoscelism: report of a case. J Wilderness Med. 1991;2:49-54.

108. Marques-da-Silva E, Souza-Santos R, Fischer ML, Rubio GBG. Loxosceles spider bites in the state of Paraná, Brazil: 1993-2000. J Venom Anim Toxins Incl Trop Dis. 2006;12(1):110-23. http://www.scielo.br/scielo.php?script=sci_ arttext\&pid=S1678-91992006000100009.

109. Yigit N, Bayram A, Ulasoglu D, Danisman T, Corak Ocal I, Sancak Z. Loxosceles spider bite in Turkey (Loxosceles rufescens, Sicariidae, Araneae). J Venom Anim Toxins incl Trop Dis. 2008;14(1):178-87. http://www.scielo.br/ scielo.php?script=sci_arttext\&pid=\$1678-91992008000100016.

110. Fischer ML, Vasconcellos-Neto J. Microhabitats occupied by Loxosceles intermedia and Loxosceles laeta (Araneae: Sicariidae) in Curitiba, Paraná, Brazil. J Med Entomol. 2005;42(5):756-65.

111. Ramires EN, Retzlaff AV, Deconto LR, Fontana JD, Marques FA, Marques-daSilva E. Evaluation of the efficacy of vacuum cleaners for the integrated control of brown spider Loxosceles intermedia. J Venom Anim Toxins Incl Trop Dis. 2007;13(3):607-19. http://www.scielo.br/scielo.php?script=sci_ arttext\&pid=S1678-91992007000300005

112. Dehghani R, Talaee R, Rafeenejad J, Seydi Rezvani R, Karimi F. Brown widow spider bite (Loxosceles sp., Araneae, Sicariidae): a case report from Kashan, Iran. Iran. J Dermatol. 2017:20:32-5.

113. Latifi M, Tabatabai M. Immunological studies on Iranian scorpion-venom and antiserum. Toxicon. 1979;17(6):617-21.

114. Zare Mirakabadi A, Mahmoodi Khatoonabadi S, Teimoorzadeh S. Antivenom injection time related effects of Hemiscorpius lepturus scorpion envenomation in rabbits. Arch Razi Inst. 2011;66(2):139-45.

115. Jalali A, Pipelzadeh MH, Taraz M, Khodadadi A, Makvandi M, Rowan EG. Serum TNF-a levels reflect the clinical severity of envenomation following a Hemiscorpius lepturus sting. Eur Cytokine Netw. 2011;22(1):5-10.

116. Seyedian R, Jalali A, Babaee MH, Pipelzadeh MH, Rezaee S. A biodistribution study of Hemiscorpius lepturus scorpion venom and available polyclonal antivenom in rats. J Venom Anim Toxins Incl Trop Dis. 2012;18(4):375-83. http://www.scielo.br/scielo.php?script=sci_arttext\&pid=S167891992012000400005

117. Jalali A, Pipelzadeh MH, Seyedian R, Rahmani AH, Omidian N. In vivo pharmacological study on the effectiveness of available polyclonal antivenom against Hemiscorpius lepturus venom. J Venom Anim Toxins Incl Trop Dis. 2011;17(2):142-9. http://www.scielo.br/scielo.php?script=sci arttext\&pid=S1678-91992011000200004

118. Lourenço WR. Scorpion incidents, misidentification cases and possible implications for the final interpretation of results. J Venom Anim Toxins Incl Trop Dis. 2016;22:21. https://doi.org/10.1186/s40409-016-0075-6.

119. Teimourzadeh SH, Khatoonabadi M, Zare Mirakabadi A, Sabiri GH. Serum enzymes studies in scorpion (Hemiscorpius lepturus) dose related envenomation in rabbits. Arch Razi Inst. 2010;65(2):83-9. 
120. Pucca MB, Roncolato EC, Campos LB, Fernandes FS, Mendes GR, Bertolini TB, et al. Experimental Tityus serrulatus scorpion envenomation: age-and sexrelated differences in symptoms and mortality in mice. J Venom Anim Toxins Incl Trop Dis. 2011;17(3):325-32. http://www.scielo.br/scielo. php?script=sci_arttext\&pid=S1678-91992011000300013.

121. Ghalim N, El-Hafny B, Sebti F, Heikel J, Lazar N, Moustanir R, et al. Scorpion envenomation and serotherapy in Morocco. Am J Trop Med Hyg. 2000; 62(2):277-83.

122. Mazzei de Dàvila CA, Dàvila DF, Donis JH, Aratade Bellabarba G, Vilarreal V, Barboza JS. Sympathetic nervous system activation, antivenin administration and cardiovascular manifestations of scorpion envenomation. Toxicon. 2002; 40(9):1339-46.

Submit your next manuscript to BioMed Central and we will help you at every step:

- We accept pre-submission inquiries

- Our selector tool helps you to find the most relevant journal

- We provide round the clock customer support

- Convenient online submission

- Thorough peer review

- Inclusion in PubMed and all major indexing services

- Maximum visibility for your research

Submit your manuscript at www.biomedcentral.com/submit
Biomed Central 